\title{
Application of Communicative Approach in College English Teaching
}

\author{
Lu WANG \\ Qiqihar Medical University \\ Qiqihar, Heilongjiang, 161000,China
}

\begin{abstract}
The traditional teaching model is mainly focused on imparting language knowledge. Teachers often adopt a teacher-centered lecture teaching model, which resulting in students' "Dumb English." In order to change this situation, college English teaching should focus on cultivating the students' communicative ability, instead of limiting to syntax or "linguistic competence", where "linguistic competence" refers to the knowledge of the rules and forms of language. Classroom teaching should be aimed at fostering communicative competence and making the classroom a place to practice communicative ability. Therefore, we must well develop students' interpersonal skills, achieve the conversion that learning language form to content, making language as a tool for students to express thoughts, feelings and information. Communicative approach is born from the purpose that provides students with a lot of language practice opportunities, which improves their interpersonal skills.
\end{abstract}

Keywords- communicative approach; college English teaching; culture

\section{INTRODUCTION}

From the early 1960s onward, the study focus gradually shifted from the structure into function, from isolated using form into the correct functions of language form in a particular social and cultural environment. The linguistics and cultural features study of language are increasingly attracting attention. The successively establishing of Sociolinguistics and Intercultural Communication has opened up a new field for the study of linguistics and language teaching. Some scholars in their interpersonal skills doctrine are more emphasizing the social characteristics of the language. Effectiveness of communication not only depends on right or wrong of language form, but also consider the social background and cultural connotation of the language forms involved. Different countries have different social systems and cultural history, so people's values, worldviews are not the same and the differences in ideological field is an objective reality, which requires us to fully consider the language cultural identity when we learn a language.

\section{OVERVIEW OF COMMUNICATIVE APPROACH}

In 1965, the American linguist Chomsky proposed distinction between language ability and language behavior. In the late 1960s, some linguists gradually realized that mastery of a language should be focused on the use of language, not just the rules and structure of language. American anthropologist Hymes proposed the concept of communicative competence. Communicative competence refers to effectively and accurately communicate with different people in a variety of occasions by using the language we learned. Linguists Widdowson, Candlin also believe the language teaching should be training language competence, not just teach them to master the language structure. This view has been accepted by Britain's function linguist Firth and Halliday and American social linguist Gumper and Labov, which became the basis of communicative approach development. Another dynamic of communicative approach came from the European Commission. In the 1970s, after the establishment of the European Union, nine kinds of different languages hinder the effective functioning of the organization. In 1971, the European Commission's cultural cooperation committee held a meeting on how to improve foreign language skills in the member states. In 1972, the American linguist Wilkin wrote a report which put forward the definition of language information communication. In 1976, Wilkin amplified the report into a book The Conceptual Outline. In 1978, Widdowson's Communicative English Teaching publishing became the basis for the rapid development of communicative approach. In 1981, Johnson and Morrow compiled Communication in Classroom, and this book clearly shows the theory and practice of the communicative approach, which provide guidance for English teachers to find suitable teaching methods.

\section{Communicative Language Teaching IN China}

In recent years, with China's accession to the WTO, foreign communications become more frequent, so the demand for comprehensive capabilities English talents has become increasingly higher. So teaching and learning relationship also concerned by people. Teachers how to teach and students how to learn become an important issue that experts, scholars and the majority of English teachers need to explore. the Ministry of Education put forward in the 2004 College English Curriculum Requirements: college English teaching goal is to develop students' English language 
proficiency, especially in listening and speaking skills, so that they can effectively use orally and written information communication in future work and social interaction, while enhancing their self-learning ability to improve the overall cultural awareness, in order to meet the needs of social development and international communication. Therefore, more and more universities have begun to abandon the traditional teacher-centered college English teaching mode. The communicative approach which advocating develop students' communicative competence has gradually became a teaching idea accepted by educational field, respected by foreign language teaching field, and more and more college English teachers also try this method. However, due to the communicative approach has big difference from traditional teaching methods, in terms of teaching process, teaching methods and teacher-student relations, communicative approach encountered a variety of problems in the practice of teaching college English.

\section{College English Teaching Situation}

At present, China's college English classroom teaching shows the feature that teacher unilaterally give text content explanation, students passively accept the teacher's indoctrination and lack of practical training of students' ability. Due to English audience are not English major, most students learning goal is CET4 and 6, so students are mostly limited to written reading ability, without listening and speaking ability training, resulting in many students could not speak English, do not understand what others are talking about. Although students' CET scores may be high, but for the needed English skills in future work is far from enough. How to change this situation, so students can foster listening, speaking and communicative ability while enhance comprehensive skill? A good tool is communicative English teaching method; I will discuss the feasibility of the application of communicative English teaching in college English classroom as well as specific implementation methods.

\section{THE PRINCIPLES AND CHARACTERISTICS OF COMMUNICATIVE ENGLISH TEACHING}

Communicative approach believes that language is a tool for human communication; social function is the most basic function of language, foreign language teaching should cultivate students' ability to communicate, teachers should select the appropriate content and teaching methods for students to grasp the social communication ability. Communicative English teaching method is based on the principles of student-centered, teacher-led. Core of communicative English teaching is that teachers should base on the characteristics of students, individualized, appropriate arranging social practice teaching activities to develop students' communicative competence. Core of communicative English teaching is to organize fun activities and practical teaching to cultivate students' basic skills in English communication, which emphasizes the language of authenticity; teachers should provide students a real language environment for students to get the actual use of language. In this process, teachers should interact with a large number of students, rather than simply teaching knowledge, the teacher is the guide organizers and participants of the whole event.

\section{ADVANTAGES AND DISADVANTAGES OF COMMUNICATIVE APPROACH IN ENGLISH TEACHING}

\section{A. Communicative Approach Is Language Rethinking from another Angle for Teacher}

Over the years, we have been teaching English as knowledge. We maintain explain grammar entry, word memory, language split into isolated language points, as long as equip students with all of this, they naturally grasp English, and communicative competence will follow. Core of communicative competence is they are able to apply what they have learned in different situations for different objects with effective communication and decent. English learners only understand the language knowledge, listening, speaking, reading and writing are superficial, so we must also master the specific communicative situation in terms of rules and policy rules. Therefore, the communicative approach allows us to further understand the purpose of English teaching, also better understand that the language learning and language use are inextricably linked.

\section{B. Communicative Approach Based on Students' Needs to Develop Students' Speaking Ability}

Choice of teaching content, establishment of teaching requirements, communicative of teaching form provide students with a lots real situations using language, the real and nature practical activities into the classroom requires students to think, to use a variety of language knowledge to complete tasks in different languages such as sub-events, group activities, role play and so on. All these activities make listening, speaking, reading and writing ability to utilization and development. The traditional teacher-centered language teaching classroom structure not only limits the number of students to participate in the activities of the session, but also limits the quality of the session activities. In communicative approach, the natural scenario of communication enable students have the opportunity to participate in a variety of creative language use activities. They are no longer restricted to the use of isolated sentences, but can converge and coherent expression, therefore, the communicative teaching develop learners' speaking ability, so that learners learn how to use real language to communicate in a real scenario, learn how to start and end of the session, learn how to cope with communication failures and changes in short, learn how to make communication smooth.

\section{Communicative Approach Enable Students Get Emotional Communication}

One idea of communicative approach is that students are more motivated to learn English because they have learned to use the language in a useful communication. In addition, teachers give students the opportunity to communicate their views through the idea of the full performance of their personality. This allows the combination of English and their 
personality and thus forms a complete emotion. Finally, the students' sense of security cooperation and communication with the students through several teachers to be strengthened in such a harmonious atmosphere of unfettered classroom, students do not have a sense of oppression, which make them more creative in language learning activities. The process of learning becomes equal communication between students and teachers, between students and students, especially interactive learning among students, more students ease the psychological pressure, eliminate the psychological barriers classroom. Second, teachers must pay attention to guide students to focus on using the language of communication rather than grammar, pay attention to language fluency instead of correctness, as they create a real language communication environment as much as possible and guide them to use the language in real life learning together.

\section{APPLICATION STRATEGIES OF COMMUNICATIVE APPROACH IN COLLEGE ENGLISH TEACHING}

\section{A. enhance students' learning interest}

In traditional grammar-translation method of teaching, teachers dominate the entire English class, so students in a passive state of learning, which is learning in order to learn. Influence by the traditional English style, the students in the classroom feel less practical use of English learning. Boring classroom atmosphere, long-term memory to repeat words and sentences translating standard, interest in learning English continually decrease, so English became a subject for graduate study, the usefulness of English itself is reduced. In the communicative approach, the interest-based classroom language communication can often inspire students to fully participate which change students from passive recipients to activists.

\section{B. Strengthen Student Understanding of Language Application and Structure}

In a grammar-translation method based English teaching class, students mainly rely on memory to learn some out of context, isolated key vocabulary and scattered grammar phenomenological method. The key is student-centered teaching, and will learn the combination of textbook knowledge with real life, so that students get language structure in everyday language communication, and further accumulated knowledge of English. In classroom teaching, teachers can guide students to transfer language material to their own language, so that students can not only master more English language materials, enhance English language sense, but also can improve English communication skills.

\section{C. create an authentic language environment}

At this stage, many students still do not have basic English communication ability, although people get high CET score, but due to lack of training, a lot of people in their daily lives, they can't understand what foreigner saying, they can neither communicate with foreigner. For this case, college English should transfer the traditional English teaching mode, adopt the communicative approach, through the change of teaching skills, college students' communicative competence will enhance and English language teaching practice will be closely knot with daily life. On the one hand constantly improve students' oral English skills, the other focus on college students' listening, speaking, reading, writing and other aspects of language skills to fully understand the meaning of pedagogy, students as teaching subject, and according to different teaching real language environment, and then continue to improve students' communicative competence.

\section{CONCLUSIONS}

In order to develop the students' ability to use English in daily life, college English teaching must get rid of the CET bondage to the communicative approach based, studentcentered, teacher-led, in the classroom, through a variety of activities to develop students' communicative ability to accommodate an increasingly competitive labor market, to become a real talent who can adapt to society's application.

\section{References}

[1] Li Xiaoqin. Communicative Approach in College English Teaching [J] Chifeng University (Natural Science), 2014, 18: 221-222.

[2] Shao Junli, Chen Cuifang, Chen Xiaofeng, Yan Kaiwen. Communicative Approach in College English Teaching [J] Chinese Journal of Environmental Management College, 2008, 01: 108-110.

[3] Li Jing. Application of Communicative Approach in New Era University English Teaching [J] Chifeng University (Natural Science), 2014,08: 238-239.

[4] Wu Da. Communicative Approach in College English Lessons in Audiovisual [J] Inner Mongolia Education (Vocational Education Edition), 2014, 11: 25-26.

[5] Song Ping. Communicative Approach of College English Teaching New liter - Tongren University as An Example [J] Jiamusi Education Institute, 2013,02: 167-168 + 198 .

[6] Wu Xiaoling. Study Using the Communicative Approach to University in New College English Teaching. [J] .Nanchang College of Education, 2013, 04: 152-153.

[7] Chen Wenjing. Communicative Approach in College English Teaching [J] science Wenhui (midmonth), 2009, 06: 156-157.

[8] Huang Liangbo. Communicative Approach Using in College English Teaching [J] Xiangtan Normal University (Social Sciences), 2009, 04: 157-158.

[9] Sun Dan. Communicative Approach in college English Teaching [J] Civil Aviation Flight University of China, 2005,03: 54-56.

[10] Yu Fang. Communicative Approach in College English Teaching [J] Science and Technology Innovation Herald, 2012, 27: 176. 